\title{
Urinary iodine and other iodine deficiency indicators in a sample of school-age children in Egypt
}

F.A. El-Mougi, ${ }^{1}$ S. Abd-El-Ghaffar, ${ }^{2}$ N.A.F Fayek ${ }^{1}$ and M.S. Mohammed ${ }^{1}$

$$
\begin{aligned}
& \text { تركيز اليود في البول والمؤشرات الأخرى على عوز اليود في عينة من الأطفال في سن المدرسة في مصر فئرس }
\end{aligned}
$$

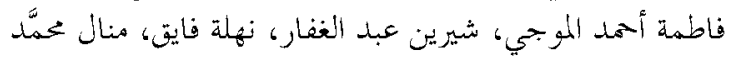

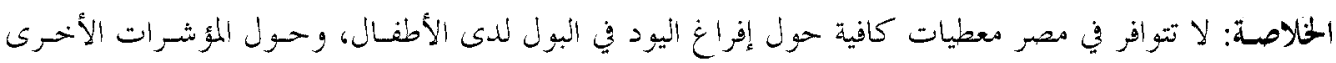

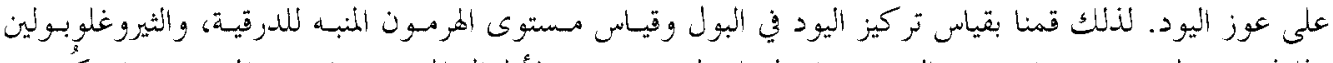

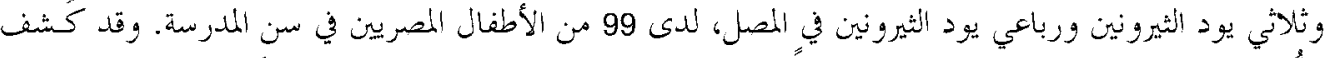

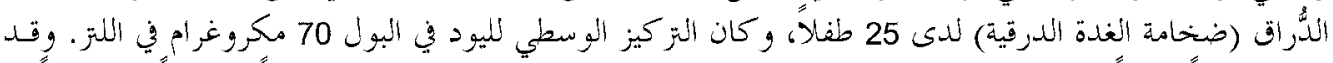

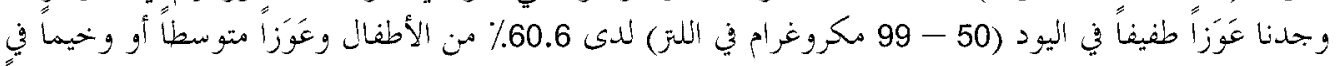

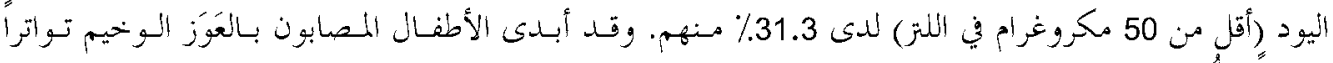

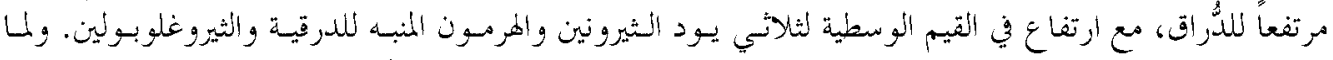

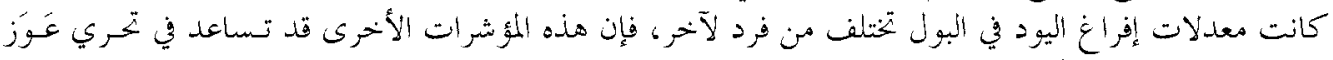

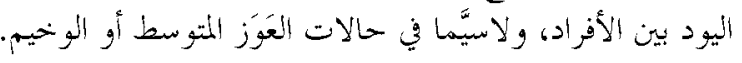

ABSTRACT Sufficient data relating urinary iodine excretion in children to other iodine deficiency indicators are lacking in Egypt. We assayed urinary iodine concentration and serum levels of thyroid stimulating hormone (TSH), thyroglobulin, free triiodothyronine $\left(\mathrm{T}_{3}\right)$ and free tetraiodothyronine in 99 school-aged Egyptian children. Goitre was found in 25 children. Median urinary iodine concentration was $70 \mu \mathrm{g} / \mathrm{L}$. We found mild iodine deficiency $(50-99 \mu \mathrm{g} / \mathrm{L})$ in $60.6 \%$ of the children and moderate to severe deficiency $(<50$ $\mu \mathrm{g} / \mathrm{L}$ ) in $31.3 \%$. The latter showed a high frequency of goitre and elevated mean serum free $\mathrm{T}_{3}, \mathrm{TSH}$ and thyroglobulin levels. Individual urinary iodine excretion rates vary, therefore these other indicators could help in screening for iodine deficiency at an individual level, especially in moderate to severe deficiency.

\begin{abstract}
L'iode urinaire et les autres indicateurs d'une carence en iode dans un échantillon d'enfants d'âge scolaire en Égypte

RÉSUMÉ On manque de données suffisantes concernant l'excrétion d'iode urinaire chez l'enfant par rapport aux autres indicateurs d'une carence en iode en Égypte. Nous avons mesuré la concentration d'iode urinaire et le taux sérique d'hormone thyréotrope (TSH), de thyroglobuline et de triiodothyronine libre $\left(\mathrm{T}_{3}\right)$ et de tétraiodothyronine libre chez 99 enfants égyptiens d'âge scolaire. Un goitre a été observé chez 25 enfants. La concentration moyenne d'iode urinaire était de $70 \mu \mathrm{g} / \mathrm{L}$. Nous avons trouvé une légère carence en iode $(50-99 \mu \mathrm{g} / \mathrm{L})$ chez $60,6 \%$ des enfants et une carence modérée à sévère $(<50 \mu \mathrm{g} / \mathrm{L})$ chez $31,3 \%$ des enfants. Ces derniers ont montré une forte fréquence du goitre et des concentrations sériques moyennes de $\mathrm{T}_{3}$ libre, de TSH et de thyroglobuline élevées. Le taux d'excrétion d'iode urinaire individuel varie ; ces autres indicateurs pourraient donc aider à dépister la carence en iode au niveau individuel, notamment dans les cas de carence modérée à sévère.
\end{abstract}

${ }^{1}$ Department of Clinical and Chemical Pathology; ${ }^{2}$ Department of Paediatrics, Faculty of Medicine, Cairo University, Cairo, Egypt.

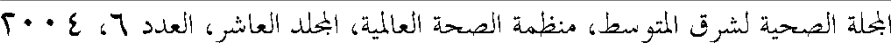




\section{Introduction}

Worldwide, iodine deficiency is the commonest cause of preventable mental retardation as well as goitrous hypothyroidism (endemic goitre), especially in developing countries. An insufficient supply of the essential micronutrient iodine, an integral part of thyroid hormones, results in impaired thyroxine production, producing a spectrum of iodine deficiency disorders including endemic goitre, cretinism, hypothyroidism, short stature and neuromuscular and neurosensorial deficit $[1,2]$.

Most iodine absorbed in the body eventually appears in the urine, so urinary iodine concentration is a good marker for very recent dietary iodine intake [1]. Iodine concentrations can, however, vary considerably from day to day and over a single day in one individual [3]. Thus, a single urinary iodine measurement is not representative of individual nutritional iodine status. Urinary iodine concentrations are useful, however, when used in cross-sectional, epidemiological surveys in population samples of appropriate size [4].

Therefore, the assessment of other indicators of iodine deficiency disorder such as the presence of goitre, serum thyroid profile or serum thyroglobulin might be helpful at an individual level if used in conjunction with urinary iodine concentration to discover iodine deficiency, especially in moderate to severe cases, and would also help for follow-up after iodine supplementation to ensure its success and to prevent consequent morbidity [5].

It has been confirmed that urinary iodine excretion assesses iodine nutrition only at the time of measurement, whereas, thyroid size reflects iodine nutrition over months or years [1]. Serum thyroglobulin has been reported to change inversely with iodine intake in all age groups [6]. On the other hand, the pattern of circulating thyroid hormones in clinically euthyroid children in areas of severe iodine deficiency has been characterized by low serum tetraiodothyronine $\left(\mathrm{T}_{4}\right)$, elevated thyroid stimulating hormone (TSH) and normal or supernormal triiodothyronine $\left(\mathrm{T}_{3}\right)$ [7].

In Egypt, endemic goitre and low urinary iodine concentration have been reported in several regions [8-11]. Most studies in Egypt, however, did not relate urinary iodine concentration with other laboratory indicators for iodine deficiency disorders.

The objective of this study was to relate the urinary iodine excretion in a sample of school-age children (5-13 years) to other indicators of iodine deficiency disorder such as thyroid profile, serum thyroglobulin and the presence of goitre. Children are at high risk of the consequences of iodine deficiency and hypothyroidism (growth and physical and mental development can be affected) and are the focus of schoolbased national surveys.

\section{Methods}

We interviewed 300 children as potential participants in this study. The inclusion criterion was age group (5-13 years) while the exclusion criteria were the presence of any systemic chronic or autoimmune disease. Informed consent was taken from all participants or their parents before entering the study. We excluded 74 of these children: 25 were outside the age range, 40 had chronic systemic disease and 9 had autoimmune disease. A total of 127 refused to participate, 55 because of fear of giving blood samples and 72 owing to lack of time.

In all, 99 school-age children 5-13 years old, 58 males and 41 females, were consecutively enrolled. These children were apparently healthy siblings and rela-

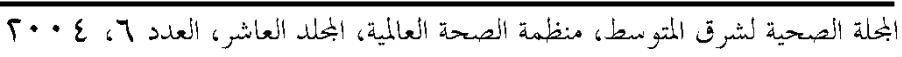


tives of patients attending the clinic of Cairo University children's hospital. People attending this hospital come from many regions of Egypt; most of them are of low or intermediate socioeconomic status.

History taking (which included questions on iodine supplementation and symptoms of hypothyroidism) and clinical examination were carried out, including neck examination by inspection and palpation for goitre according to World Health Organization (WHO) classification [1]. Blood samples (5 $\mathrm{mL}$ venous blood) were taken from each child. Sera were separated and divided into 2 aliquots for assay of thyroid hormones. One was used for serum free $\mathrm{T}_{3}$ and free $\mathrm{T}_{4}$ by solid phase radioimmunoassay [12], and serum TSH by solidphase immunoradiometric assay (Allegro highly sensitive TSH kit, Nichols Institute Diagnostics, San Juan Capistrano, California). The second aliquot was used for assay of serum thyroglobulin by chemiluminescent immunoassay using the automated Immulite analyser [13]. All commercial kits were supplied by DPC (Diagnostic Products Corporation, Los Angeles).

A morning spot urine sample was obtained from each child in a clean cup and stored at $-20{ }^{\circ} \mathrm{C}$ until assayed for urinary iodine. Urine was digested with ammonium persulfate to get rid of interfering substances, then iodide was measured by its catalytic action on the reduction of ceric ammonium sulfate (yellow) to the cerous form (colourless), coupled to the oxidation of arsenite to arsenate (Sandell-Kolthoff reaction) [14]. All chemicals were supplied by Sigma (Saint-Quentin, France).

We used SSPS, version 9 for data processing. Quantitative data were presented as mean and standard deviation for normally distributed variables and mean and percentiles for skewed distributions. For comparison of means, the Student $t$-test or Mann-Whitney test was used. For qualitative data chi-squared was used for comparison. Correlation between variables was done and Spearman's rank correlation coefficient calculated. All tests were 2-tailed and considered statistically significant at $P$ $<0.05$.

The WHO cut-off points for urinary iodine levels were used to define iodine deficiency as well as to classify the severity of the deficiency: optimal urinary iodine concentration $>99 \mu \mathrm{g} / \mathrm{L}$; mild deficiency 50 $99 \mu \mathrm{g} / \mathrm{L}$; moderate deficiency $20-49 \mu \mathrm{g} / \mathrm{L}$; and severe deficiency $<20 \mu \mathrm{g} / \mathrm{L}[1]$.

\section{Results}

There were 99 children in the study group, 59 male and 41 female. Mean age was 9.1 years (standard deviation 2.8), range 5-13 years.

Classification according to urinary iodine concentration followed the WHO cutoff points for iodine deficiency levels is shown in Table 1. Urinary iodine concentration was not normally distributed; the median level was calculated as $70.0 \mu \mathrm{g} / \mathrm{L}$ with the 25th and 75th percentiles being $33.0 \mu \mathrm{g} / \mathrm{L}$ and $85.0 \mu \mathrm{g} / \mathrm{L}$ (Table 1). No significant difference between males and females was seen in the different grades of iodine deficiency $(P=0.06)$.

By clinical examination, goitre was found in 25 of the children we studied. Urinary iodine concentration was decreased in all goitrous children (Table 2). Goitre was present in $64.5 \%$ of children who had moderate or severe iodine deficiency (mostly grade 2 goitre) compared to only $8.3 \%$ of children with mild deficiency (mostly grade 1 goitre). The difference was statistically significant $(P<0.01)$. Goitre was not

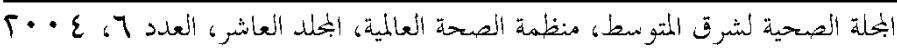




\begin{tabular}{|c|c|c|}
\hline $\begin{array}{l}\text { Classification } \\
\text { (urinary iodine) }\end{array}$ & $\begin{array}{c}\text { Median, } \\
70 \mu g / L \\
\text { No. }\end{array}$ & $\begin{array}{c}\text { Interquartile } \\
\text { range, } \\
33-85 \mu g / L \\
\%\end{array}$ \\
\hline 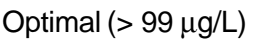 & 8 & 8.1 \\
\hline $\begin{array}{l}\text { Mild deficiency } \\
\qquad(50-99 \mu \mathrm{g} / \mathrm{L})\end{array}$ & 60 & 60.6 \\
\hline $\begin{array}{l}\text { Moderate deficiency } \\
(20-49 \mu \mathrm{g} / \mathrm{L})\end{array}$ & 27 & 27.3 \\
\hline $\begin{array}{l}\text { Severe deficiency } \\
\qquad(<20 \mu \mathrm{g} / \mathrm{L})\end{array}$ & 4 & 4.0 \\
\hline
\end{tabular}

present in the children who did not have iodine deficiency.

Elevated serum thyroglobulin $(>40 \mathrm{ng} /$ $\mathrm{mL})$ was found in 6 children (6.1\%); all had moderate or severe iodine deficiency. They constituted $19.4 \%$ of the children who had moderate or severe iodine deficiency. Similarly, increased serum TSH
(> $6.5 \mu \mathrm{IU} / \mathrm{ml})$ occurred in $13(41.9 \%)$ of the 31 children who had moderate or severe iodine deficiency. Cases with optimal urinary iodine concentration had no elevation of serum TSH or serum thyroglobulin (Table 2).

Mean serum free $\mathrm{T}_{3}$, serum TSH and serum thyroglobulin were significantly elevated in the children with moderate or severe iodine deficiency compared to those with optimal urinary iodine concentration or mild iodine deficiency $(P<0.001$ for both). However, free $\mathrm{T}_{4}$ levels were not significantly different between groups $(P$ $=0.9$ ) $($ Table 3 ). Moreover, a negative correlation was observed between urinary iodine level and serum TSH $\left(r_{s}=-0.34 ; P\right.$ $<0.001$ ).

\section{Discussion}

Our results showed a high prevalence of iodine deficiency in the children we studied; only $8.1 \%$ had optimal urinary iodine concentration according to the WHO cutoff points for urinary iodine levels [1]. One

Table 2 Number of children with disturbance of thyroid function according to iodine deficiency category

\begin{tabular}{|c|c|c|c|c|c|c|}
\hline \multirow[t]{3}{*}{ Variable } & \multicolumn{6}{|c|}{ lodine deficiency level of children } \\
\hline & \multicolumn{2}{|c|}{ None $^{a}(n=8)$} & \multicolumn{2}{|c|}{$\operatorname{Mild}^{b}(n=60)$} & \multicolumn{2}{|c|}{$\begin{array}{c}\text { Moderate \& } \\
\operatorname{severe}^{c}(n=31)\end{array}$} \\
\hline & No. & $\%$ & No. & $\%$ & No. & $\%$ \\
\hline Goitre & 0 & - & 5 & $8.3^{\star *}$ & 20 & $64.5^{\star *}$ \\
\hline $\begin{array}{l}\text { Increased serum TSH } \\
\quad(>6.5 \mu \mathrm{lU} / \mathrm{mL})\end{array}$ & 0 & - & 0 & - & 13 & 41.9 \\
\hline $\begin{array}{l}\text { Increased serum thyroglobulin } \\
\qquad(>40 \mathrm{ng} / \mathrm{mL})\end{array}$ & 0 & - & 0 & - & 6 & 19.4 \\
\hline
\end{tabular}

البملة الصحية لشرق المتوسط، منظمة الصحة العالمية، ابخلد العاشر، العدد ج، ع • +? 


\begin{tabular}{|c|c|c|c|}
\hline Variable & $\begin{array}{l}\text { Optimal and } \\
\text { mild deficiency } \\
(n=68) \\
\text { Mean (SD) }\end{array}$ & $\begin{array}{c}\text { Moderate and } \\
\text { severe deficiency } \\
(n=31) \\
\text { Mean (SD) }\end{array}$ & P-value \\
\hline Age (years) & $9.0(2.8)$ & $9.4(2.8)$ & 0.6 \\
\hline Free $T_{3}(p g / m L)$ & $3.29(0.58)$ & $4.76(0.67)$ & $<0.001$ \\
\hline Free $T_{4}(n g / d L)$ & $1.53(0.24)$ & $1.52(0.36)$ & 0.9 \\
\hline TSH $(\mu \mathrm{IU} / \mathrm{mL})$ & $2.35(0.99)$ & $7.09(6.52)$ & $<0.001$ \\
\hline $\begin{array}{l}\text { Thyroglobulin } \\
\text { (ng/mL) }\end{array}$ & $14.23(8.38)$ & $23.31(19.72)$ & $<0.001$ \\
\hline 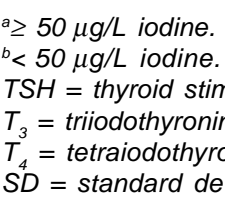 & $\begin{array}{l}\text { ulating hormone. } \\
\text { e. } \\
\text { nine. } \\
\text { viation. }\end{array}$ & & \\
\hline
\end{tabular}

quarter of the children had clinical goitre. These results could signify that iodization of salt may not be adequate or they may be affected by consumption of goitrogens.

Previous studies reporting endemic goitre in Egypt are consistent with the results of this study. In Cairo, a prevalence of $13.5 \%$ has been reported in primary school children, with the highest prevalence (27.1\%) in north Cairo [15]. In Upper Egypt, the overall prevalence of goitre was $34.6 \%$ in one study [16]. Other studies reported that the highest prevalence of goitre in Egypt (82.3\%) was in the New Valley [8] followed by Minia (36.9\%), Assuit (36.8\%), Sohag (30.1\%) in Upper Egypt [9] then Kafr El Sheikh (27.1\%) [10] and Aswan (17.5\%) [11].

The high prevalence observed among the children we studied as well as the previous studies is in contrast to the cut-off level recommended by WHO [1]. It is recommended that a total goitre rate of 5\% or more in schoolchildren $6-12$ years of age is used to signal the presence of a public health problem. This recommendation is based on the observation that in a normal, iodine-replete population, the prevalence of goitre should be quite low. The cut-off point of 5\% allows both for some margin of error in goitre assessment and for goitre that may occur in iodine-replete populations due to other causes such as goitrogens and autoimmune thyroid disease [1].

Our results are also in agreement with the high prevalence encountered in countries such as in Turkey, where goitre prevalence ranged from $5 \%$ to $56 \%$, indicating severe to moderate iodine deficiency in 14 , and mild iodine deficiency in 6 , of the cities surveyed [17]. In the Islamic Republic of Iran, goitre prevalence was $60 \%$; after iodine supplementation, this dropped to $47 \%$ [18]. A lower prevalence rate was found in Indonesia: $12.5 \%$ in Bali, and $8.0 \%$ in Java and Sumatra [19]. Different prevalence rates were seen in India, ranging from $0.0 \%$ in some areas [20], to $30.2 \%$ in oth-

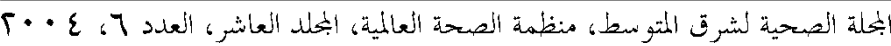


ers [21]. Mild to severe iodine deficiency was also reported in 32 European countries in the late 1990s, and they still have not reached a state of iodine sufficiency [22].

The urinary iodine excretion rates recorded in our study agree with those reported in Bali-Indonesia, where the median urinary iodine value was $81.0 \mu \mathrm{g} / \mathrm{L}$, with $58.3 \%$ of the values below $100 \mu \mathrm{g} / \mathrm{L}$ (mild to severe deficiency) and only $14.7 \%$ of the values above $200 \mu \mathrm{g} / \mathrm{L}$ [19]. In the Islamic Republic of Iran, median urinary iodine concentration was $76 \mu \mathrm{g} / \mathrm{L}$; this increased to $185 \mu \mathrm{g} / \mathrm{L}$ after iodine supplementation [18]. In Turkey, median urinary iodine concentration ranged between $14 \mu \mathrm{g} / \mathrm{L}$ (severe deficiency) and $78 \mu \mathrm{g} / \mathrm{L}$ (mild deficiency) [17]. In studies done in the 1990s in Egypt, values ranged between $15.1 \mu \mathrm{g} / \mathrm{L}$ in Kafr El Sheikh and $8.9 \mu \mathrm{g} / \mathrm{L}$ in the New Valley [8-11]. Another study reported a median urinary iodine concentration of $5.0 \mu \mathrm{g} / \mathrm{L}$ in goitrous children in Upper Egypt [16].

Our study revealed increased free $T_{3}$ in patients with moderate and severe iodine deficiency when compared with those with mild iodine deficiency. Increased serum TSH as well as elevated serum thyroglobulin levels were found only in patients with moderate and severe iodine deficiency.

Similar results were reported in 1993 in Indians of southern Venezuela by Cooper et al. who reported that $71 \%$ of children had a thyroid volume above normal and iodine deficiency was associated with predictable higher serum free $\mathrm{T}_{3}$ and TSH concentrations [23].

It has been mentioned that the pattern of circulating thyroid hormones in clinically euthyroid children in areas of severe iodine deficiency is characterized by low serum $\mathrm{T}_{4}$, elevated TSH, and normal or supernormal $\mathrm{T}_{3}$. The mechanisms responsible for this pattern are unclear but may include thyroidal secretion of $\mathrm{T}_{4}$ and $\mathrm{T}_{3}$ in the pro- portion in which they exist within the gland, preferential secretion of $\mathrm{T}_{3}$, or increased peripheral conversion of $T_{4}$ to $T_{3}$. The shift to increased $T_{3}$ secretion and increased serum $T_{3}: T_{4}$ ratio may play an important role in the adaptation to iodine deficiency because $T_{3}$ possesses about 4 times the metabolic potency of $\mathrm{T}_{4}$, but requires only $75 \%$ as much iodine for synthesis [5].

It has been reported that plasma thyroglobulin levels increase in iodine deficiency and in organification defects. Insufficient iodine intake induces proliferation of thyroid cells, which results in hyperplasia and hypertrophy. This leads to an enhanced turnover of thyroid cells, which release thyroglobulin into the circulation [6]. In this setting, serum thyroglobulin reflects iodine nutrition over a period of months or years, in contrast to urinary iodine concentration which assesses more immediate iodine intake. The results of our study match well with this hypothesis as $41.9 \%$ of participants with moderate and severe iodine deficiency had elevated serum TSH and $19.4 \%$ had elevated serum thyroglobulin and an inverse correlation was also found between urinary iodine and serum TSH. After iodine depletion, thyroglobulin rises before TSH shifts to higher values and long before goitre develops. Following iodine supplementation, thyroglobulin normalizes before thyroid volume has decreased. Therefore, an increase in TSH and/or thyroglobulin could be considered the first sign of a fall in effectiveness of iodized oil injection [7].

It has to be stressed, however, that the sample size in this study was not large enough to comment adequately on the iodine status of the population. The sample size was constrained by the limited financial resources available, therefore, conclusions should be limited to the relation of

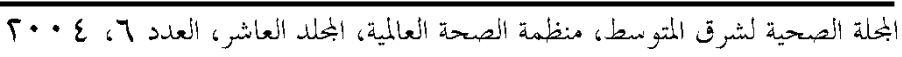


urinary iodine excretion to other indicators of iodine deficiency. Urinary iodine excretion was highly variable in our sample as has been documented before [3]. Other indicators for iodine deficiency disorder (free $\mathrm{T}_{3}$, free $\mathrm{T}_{4}$ serum $\mathrm{TSH}$, serum thyroglobulin and presence of goitre) are interrelated with urinary iodine excretion and can be used as monitors for the screening of iodine deficiency at an individual level, especially in people with moderate to severe deficiency.
These indicators could be also used for monitoring the success of an iodine supplementation programme. More studies need to be done on a larger scale for assessment of the current status of iodine deficiency in Egypt and for supervision of proper iodine supplementation, which is required to prevent iodine deficiency disorder with all its consequent morbidities.

\section{References}

1. Assessment of iodine deficiency disorders and monitoring their elimination. A guide for programme managers, 2nd ed. Geneva, World Health Organization, 2001 (WHO/NHD/01.1).

2. Angermayr L, Clar C. lodine supplementation for preventing iodine deficiency disorders in children. Cochrane database of systematic reviews, 2004, (2).

3. Als $\mathrm{C}$ et al. Urinary iodine concentration follows a circadian rhythm: a study with 3023 spot urine samples in adults and children. Journal of clinical endocrinology and metabolism, 2000, 85:1367-9.

4. Delange $\mathrm{F}$ et al. Determining median urinary iodine concentration that indicates adequate iodine intake at population level. Bulletin of the World Health Organization, 2002, 80(8):633-6.

5. Mirmiran P, Hajipour R, Azizi F. lodized salt consumption maintains euthyroidism in iodine deficient hypothyroid subjects. International journal for vitamin and nutrition research, 2003, 73(3):18791.

6. Gons $\mathrm{MH}$ et al. Concentration of plasma thyroglobulin and urinary excretion of iodinated material in the diagnosis of thyroid disorders in congenital hypothyroidism. Acta endocrinologica, 1983, 104(1):27-34.
7. Mirmiran P, Kimiagar M, Azizi F. Threeyear survey of effects of iodized oil injection in schoolchildren with iodine deficiency disorders. Experimental and clinical endocrinology \& diabetes, 2002, 110(8):393-7.

8. Report on the assessment of the prevalence of iodine deficiency disorders in New Valley governorate. Alexandria, High Institute of Public Health \& United Nations Children's Fund, 1993.

9. Report on the assessment of the prevalence of iodine deficiency disorders in Minia, Assuit and Sohag governorates. Alexandria, High Institute of Public Health \& United Nations Children's Fund, 1996.

10. Report on the assessment of the prevalence of iodine deficiency disorders in Kafr El Sheikh governorate. Alexandria, High Institute of Public Health \& United Nations Children's Fund, 1996.

11. Report on the assessment of the prevalence of iodine deficiency disorders in Aswan governorate. Alexandria, High Institute of Public Health \& United Nations Children's Fund, 1995.

12. Ekins RP. The radioimmunoassay of free thyroid hormones in blood. In: Albertini A, Ekins RP, eds. Free hormones in blood.

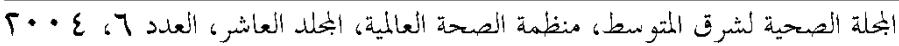


Amsterdam, Elsevier Biomedical Press, 1982:73-90.

13. Spencer CA, Wang CC. Thyroglobulin measurement. Techniques, clinical benefits, and pitfalls. Endocrinology and metabolism clinics of North America, 1995, 24(4):841-63.

14. Ohashi T et al. Simple microplate method for determination of urinary iodine. Clinical chemistry, 2000, 46(4):529-36.

15. El-Sayed NA et al. Assessment of the prevalence of iodine deficiency disorders among primary school children in Cairo. Eastern Mediterranean health journal, 1995, 1(1):55-63.

16. El-Sayed NA et al. lodine deficiency disorders among school children in Upper Egypt: an epidemiologic study. Journal of tropical pediatrics, 1998, 44(5):270-4.

17. Erdogan $\mathrm{G}$ et al. lodine status and goiter prevalence in Turkey before mandatory iodization. Journal of endocrinological investigation, 2002, 25(3):224-8.

18. Azizi F, Navai L, Fattahi F. Goiter prevalence, urinary iodine excretion, thyroid function and anti-thyroid function and anti-thyroid antibodies after 12 years of salt iodization in Shahriar, Iran. International journal for vitamin and nutrition research, 2002, 72(5):291-5.

19. Djokomoeljanto $R$ et al. The ThyroMobil model for standardized evaluation of iodine deficiency disorders control in Indonesia. Thyroid, 2001, 11(4):365-72.

20. Chandra AK, Ray I. Evaluation of the effectiveness of salt iodization status in Tripura, north east India. Indian journal of medical research, 2002, 115:22-7.

21. Singh PN, Ahmad J. Goiter in rural area of Aligarh district. Indian journal of physiology and pharmacology, 2002, 46(1): 102-6.

22. Delange F. lodine deficiency in Europe and its consequences: an update. European journal of nuclear medicine and molecular imaging, 2002, 29(suppl. 2): S404-16.

23. Cooper DS et al. The thyroid status of the Yanomamo Indians of southern Venezuela: 1992 update. Journal of clinical endocrinology and metabolism, 1993, $77(3): 878-80$. 